\title{
Tourist destinations positioning: From indexes to managerial implications
}

\author{
Jean Paul Lemaire ${ }^{1}$, Milena Viassone ${ }^{2, *}$ \\ ${ }^{1}$ ESCP Europe, Paris, France \\ ${ }^{2}$ Department of Management, University of Turin, Turin, Italy \\ Email address: \\ jplemaire@escpeurope.eu (J. P. Lemaire), milena.viassone@unito.it (M. Viassone)
}

\section{To cite this article:}

Jean Paul Lemaire, Milena Viassone. Tourist Destinations Positioning: From Indexes to Managerial Implications. Journal of Investment and Management. Special Issue: Attractiveness and Governance of Tourist Destinations. Vol. 4, No. 1-1, 2015, pp. 30-38.

doi: 10.11648/j.jim.s.2015040101.15

\begin{abstract}
Despite the numerous attempts to define Tourist Destination Attractiveness (TDA) and Governance (TDG), there are no identified contributions concerning the analysis of these elements in a systemic way. This paper creates a TDA-TDG matrix able to map destinations on the basis of these dimensions, in order to draw development strategies. Drivers of TDA and TDG are chosen by means of literature and validated by 15 tourism stakeholders. TDA index is got throughout Delphi method while TDG index throughout an adaptation of the SERVPERF questionnaire. The paper results in a mapping of tourist destinations that allows tourist managers to draw paths of development.
\end{abstract}

Keywords: Tourist Destination, Destination Attractiveness, Destination Governance, Delphi Methodology, Likert Scale, SERVPERF Questionnaire

\section{Introduction}

In the last decades the study of tourist destinations has been more and more at the centre of international academic debate. In particular the competition in global tourism market is increasing thanks to a large number of emerging destinations putting the traditional ones under pressure to innovate and to enhance their quality in order to remain competitive [1]. Many authors [2, 3] have recognized importance of tourism attractiveness as one of the most important dimensions in tourist destination studies. Anyway, the management of tourist destinations involves a high number of stakeholders who are interconnected among themselves and could be more or less ready to cooperate together. This can cause several problems of coordination that can negatively affect the attractiveness of a destination. For these motivations several researches have been carried out on the way the government manages such issues of public interest and promotes suitable industrial policies [4].

Despite the numerous attempts to define and measure tourist destination attractiveness and governance, there are no identified contributions concerning the analysis of these important elements in a systemic way. This research aims at bridging this gap through the proposal of offering a descriptive and prescriptive framework capable of measuring the level of attractiveness and governance of a tourist destination, allowing to assess how to improve its level. In order to carry out this objective, this paper designs both an index of TDA and of TDG which could be associated in a matrix allowing to position any touristic destination, thus getting a classification of possible tourist destinations on the basis of their position in such a matrix leading, for their respective stakeholders, to improve the ranking of the destinations they administrate.

Taking into account the growing interest for these important topics of touristic competition, the purpose of this paper consists of creating a TDA-TDG matrix able to map tourist destinations on the basis of two variables (governance and attractiveness) in order to suggest possible development strategies to the concerned stakeholders.

- The first step of the research process designs an index of tourist destination attractiveness to be validated by a panel of experts (authorities, tourist operators, tourists, academics), throughout the Delphi method: TDA dimensions/indices will stem from the review of literature, then validated and weighted by the Delphi panel before being segmented by SPSS, in order to create the TDAI (Tourist Destination Attractiveness Index).

- The second step measures the level of governance throughout the TDGI (Tourist Destination Governance Index), upon the basis of a questionnaire -sent to a 
sample of stakeholders (governors, tourist managers, organizations, academic, tourists)-, asking them to express their opinion towards the characteristics of governance on the basis of a 5-point Likert Scale. This questionnaire is composed of 16 items and organized according to five dimensions of governance identified through the literature review.

This paper covers successively:

- a review of international literature providing definitions, main theories and characteristics of tourist destination attractiveness and governance;

- a description of the respective methodological approach of TDAI and TDGI and of the design of the research model supported by literature and validated by the selected stakeholders;

- an assessment of the proposed methodology and of the possible consecutive strategies which could be implemented.

\section{Literature Review}

\subsection{The Attractiveness of Tourist Destinations}

The concepts of destination competitiveness and attractiveness largely differ because they consider tourist destination from different points of view: attractiveness stems from the tourist perception, while competitiveness is a concern of destination stakeholders [5].

Destination attractiveness would be a mental construct of the potential visitors or, better, a mental image of the destination that is formed on the basis of the image they could have of the local assets accessible at the destination [1].

Before analyzing the drivers affecting tourist destination attractiveness, it is necessary to provide a definition both of destination and of attractiveness. Cracolici and Nijkamp [3] consider destination as 'the 'supplier' of spatial tourist services with distinct attractiveness features (or attributes), which have to be managed effectively and efficiently" while attractiveness is referred as "the extent to which the availability, quality and management of local tourist services satisfies the needs of the customer". Formica and Uysal [6] consider destination attractiveness as the relationship between the availability of local assets and their importance as perceived by the tourist. In particular, according to $\mathrm{Hu}$ and Ritchie [7] the attractiveness of a destination reflects the feelings, beliefs, and opinions that individuals have about a destination perceived capacity to provide satisfaction in relation to their special vacation needs. Cuccia and Rizzo [8] explored the cultural attractiveness of tourist destinations and evaluate the role of cultural tourism in tourism seasonality. Cracolici and Nijkamp [3] analyze tourist attractiveness at a specific level, which is the regional one, while Viassone [2] analyzes this topic with reference to a particular category of tourist (the young one).

The attractiveness of a tourist destination can be led by several drivers and their measure could be very useful both for assessing attractiveness of tourist segment and for determining the main pulling factors of each considered destination [1].

Several researchers have focused their attention on these factors: for example, Ritchie and Crouch [9] find that tourist destination attractiveness is affected by seven different types of driver, i.e., physiography and climate, culture and history, mix of activities, special events, entertainment, superstructure and market ties. UNWTO [10] identifies five main categories of these: natural tourist resources, cultural and historical heritage in tourism, climate conditions, infrastructure, tourist services and facilities. Cracolici and Nijkamp [3] consider as main drivers of tourist destination attractiveness: natural and cultural resources, amount and quality of accommodation and restaurants, accessibility to transportation systems, all the activities available at the destination (the spectrum of choices for the tourist-consumer), tourist safety and local resident behavior. Jin et al. [11] tested dimensions of exhibition destination attractiveness in the Mainland China context from the perspective of exhibitors and find how destination attractiveness is a higher order construct composed of six factors:

cluster effect 1 (host city leadership in the industry), venue facilities,

cluster effect 2 (host city/region as a source of exhibitors), destination leisure environment, destination economic environment and accessibility.

Amelung and Nicholls [12] propose the first known empirical analysis of the potential impact of climate changes on Australia's tourism industry, based on projected shifts in climatic attractiveness for Australia's major tourism destinations over the coming century. They explain how these projected changes affect the flows of tourists into and around Australia, tourism planning, development and management.

In a recent study with particular reference to the young people, Viassone [2] individuates as elements considered in the choice of a tourist destination: safety, accessibility of the place/destination, hygiene, natural variables, cultural variables, accommodations, transport, entertainment and wellness and possibility of organizing congresses.

These contributions leads to a proposal of drivers of tourist destination attractiveness on which, after a process of evaluation, will rely the prescriptive model Tourist Destination Attractiveness/Tourist Destination Governance.

\subsection{Governance of Tourist Destinations}

The management of tourist destination is not simple because of the dynamics of interests and benefits sought by stakeholders: they create numerous links and interdependencies among themselves; often they do not cooperate and could have different development vision. More and more researchers on tourist destination management have paid attention to the way the government manages public issues and make suitable industrial policies [4].

In 2009, Eagles [13] defined the governance as a process by which organizations decide who take the responsibility to choose and who pays the price.

The concept of governance concerns "how societies are 
governed, ruled or "steered", and thus it involves the processes for regulating and mobilizing social action and for producing social order" [14]. This includes hierarchical tiers of formal government, networks of actors beyond government, communities and also markets [15].

Several researchers analyze the topic of tourist destination governance providing a comprehensive definition, describing different types of governance models or key problems of governance [16]. Governance can be characterized either by more diffuse policy networks and interaction with market mechanisms (i.e. what occurs in many advanced capitalist nations) or by a comparatively more hegemonic State (as in China) [17].

Different theories for destination governance have been elaborated like, for example, local elites holder theory [18], property rights theory [19], explaining why some individuals and organizations are more influential than others, the agency relationships problem $[20,21]$ between principals and agents observed in any type of organization, transaction cost economics [22] that explains the level of integration of organizations and institution in some destinations, and, finally, resource dependence theory [23]. These concepts and models are used in order to discuss different empirical case studies [24-27]. They refer to three different dimensions to study destination governance: the complexity of the destination, the interplay of public and private organizations and the resource interdependency. Beritelli et al. [24] analyze two different pattern of tourism destination governance that give a brief definition of each of these models.

A good explanation of implicit destination governance (multiple relationships relying on interdependencies, communication, trust, consensus, etc.), considered as the reason for the success or failure of collective policies and actions, is provided by Beritelli [28] throughout different dimensions applyied in his social-network analysis of elite individuals. These dimensions are:

- Network vs. Hierarchy: according to Beritelli [28], behind the network structure, there is an underlying hierarchy, so that decisions occur neither democratically nor randomly and destination planning and development are manageable upon the basis of the hierarchical behavior: according to Simon [29], the grouping of informal organizations must be hierarchically structured and could be measured; while, referring to different measures of structure, Krackhardt [30] individuates connectedness (measures the belonging of actors to a common system), hierarchy (measures the extent to which it is possible to speak of an organizational cascade), graph efficiency (that assesses the redundancies of connections inside the organization), least upper boundedness $(L U B)$ (that measures hierarchy in terms of the direction of the line-in-command) [31, 28].

- Cooperative vs. non-cooperative behavior: cooperative behavior in tourist destination communities is a very important condition in order to achieve a sustainable planning and development; this behavior turns out to be worthwhile if there is a payoff based on a strategy maximizing advantages. According to Beritelli [28], this cooperative behavior among actors and stakeholder groups in tourist destinations is an interpersonal business . It requires reciprocal sympathy. For this author, tourist destination communities distinguish themselves over all by autonomous key actors. This opinion is also supported by Tang and Tang [32] who considers that some collaborative actions [33] have been at the origin of governance networks, and that they can be considered as an indispensable support to decision-making and strategy-definition, when adapting to global changes. The premise of a tourist destination management is that, throughout cooperative planning, the effectiveness of the joint interactions among destination stakeholders can be improved to the benefit of individual stakeholders [34].

- Consensus/involvement

vs.

non-consensus/non-involvement: even if there is a large consensus on the fact that community-based tourism planning, with a high level of collaboration involving relevant stakeholders, increases effectiveness in enhancing destination strategies [35, 36]. Generally the latter are formulated by a limited number of people, an elite [37], and they are not always accepted or shared by everybody. Beritelli [28] shows how (1) explicit consensus doesn't relate to implicit consensus; (2) the necessary implicit consensus refers to a collective intelligence that allows mass collaboration and resides in individuals' and groups' perception [38]. According to March and Wilkinson [39] performance of a tourist destination particularly depends on the level of cohesion among the various actors/stakeholders present in the destination. Participation by a diverse range of actors in tourism decision-making can potentially enhance the democratic processes and ownership, widely associated with sustainable development [14].

- Openness vs. closure [28]: the existence of a trade-off between openness of a destination elite network and the preservation of the local culture and, thus, implicit governance mechanisms and routines has been pinpointed [40].

- In addition, Nunkoo et al. [41] underline how political trust is considered as important as power for good governance of tourism. Their study shows how perceived economic and political performance of institutions, in the one hand, residents' power in tourism and interpersonal trust, in the other, are valuable determinants of political trust in tourism institutions and it finds also an important relationship between public trust and political support for tourism.

\section{Methodology}

In recent years, the growing interest in tourist destination attractiveness (TDA) and governance (TDG) has had an influence on the study of tourism destinations. Despite the numerous attempts to define tourist destination attractiveness and governance, there are no identified contributions concerning the analysis of these important elements in a 
systemic way. For this reason this theoretical study tries to provide a descriptive and prescriptive framework in order to classify tourist destination upon the basis of their level of attractiveness and their type of governance.

This could represent a starting point for developing specific strategies for different destinations. The research model developed here, relying on tourist destination attractiveness drivers is based on variables inspired by the literature and validated by 15 selected stakeholders (Authorities, Academics, Tourist firms/organizations, Tourists) by means of semi-structured interviews conducted in December 2013: tourist flows, accessibility to the place/destination, natural elements, climate conditions, cultural attractions, accommodation, recreational attractions, prices level and public investments. These are considered those that strongly affect tourist attractiveness by stakeholders on the base of their experience.

The measure of a tourist destination attractiveness has been obtained by means of the Delphi Method [42, 43] (Dalkey, 1969, Okoli and Pavlovski, 2004), an iterative process that, throughout semi-structured interviews, allows to ask stakeholders of different origin,

- the validation of a theoretical framework on the basis of criteria of relevance, accessibility and transferability [44, 45];

- the weighting of different drivers of the destination attractiveness by distributing 100 scores among these drivers, upon the basis on their importance in the definition of TDA.

- In a second step of the analysis,

- scores assigned to each driver must be shared among different sub-drivers by selected stakeholder

- and then, throughout SPSS, these sub-drivers will be segmented in 4 classes containing the same portion of population. In this way a different score will be assigned to each sub-driver according to whether it belongs to class 1 (the lowest level), 2, 3 ore 4 (the highest level). The sum of scores assigned to different sub-drivers allows to get nine different partial indices reflecting the tourist destination attractiveness with reference to single variables. The sum of these indices results in the TDAI (Tourist Destination Attractiveness Index):

$\mathrm{TDAI}=\mathrm{TFS}+\mathrm{AS}+\mathrm{NES}+\mathrm{CCS}+\mathrm{CAS}+\mathrm{ACS}+\mathrm{RAS}+\mathrm{PLS}+\mathrm{PIS}$

where

TFS: tourist flows scores

AS: accessibility scores

NES: natural elements scores

CCS: climate conditions scores

CAS: cultural attractions scores

ACS: accommodation scores

RAS: recreational attractions scores

PLS: price level scores

PIS: public investment scores that can assume a low, quite low, discrete, quite high or high level.

At the same way, with respect to the tourist destination governance, most papers focus on single or multiple case studies [24, 25] and involve the institutions/stakeholders point of view $[46,47]$.

The framework adopted here, describing tourist destination governance, chooses the individual as object of research and an adaptation of the social network analysis as methodology [28, 48]. In this paper is presented the logical development of the state-of-the-art in destination planning and management, as well as the recent research field of "destination governance": in particular are used the dimensions described by Beritelli [28] in his networking analysis and Nunkoo et al. [41], but evaluated throughout a Likert Scale that better allows to get an evaluation of the different dimensions of implicit destination governance, both by "ruling" and "ruled" individuals.

In fact, in order to provide a measure of TDG, it has been chosen an adaptation of the SERVPERF questionnaire - created in 1992 by Cronin e Taylor [49] - composed, in this case, only by 16 sentences organized according to the five dimensions affecting destination governance (network vs. hierarchy, cooperative vs. non-cooperative, consensus/involvement vs. non-consensus/non-involvement, opening vs. closure, political trust vs. non-political trust).

In this case, on a 5-points Likert scale (between « I completely disagree» and «I completely agree») [50], individuals must indicate the level of agreement with reference to the different sentences about TDG. In order to evaluate the TDG in a global way, it will be, first of all, necessary to evaluate the TDG perceived by each single tourist involved in the survey.

This will result in the average $\mathrm{Qj}$ of judgments provided by the same to the 16 sentences $\left(Q_{i j}\right)[51]$ :

$$
\text { TDGI }_{\mathrm{j}}=\frac{\sum_{\mathrm{i}=1}^{16} \mathrm{TDGI}_{\mathrm{ij}}}{16}
$$

Afterwards, the average of the values of Qj registered for all the users involved must be computed [50]:

$$
\text { TDGI }=\frac{\sum_{j=1}^{n} \text { TDGI }_{j}}{n}
$$

Generally, values higher than 3 indicate a good level of stakeholders' agreement vs. TDG [44]. The statistical analysis of data will be carried out through SPSS 19.0 suite.

After these two steps, we are able to cross the two variables object of our study (TDA and TDG) and, on the basis of values they assume, to classify them in seven different categories.

The position of each destination in the matrix TDA/TDG allows drawing possible future paths of action. No missing data were found.

\section{From Tourist Destinations' Attractiveness and Governance Indicators to Indexes}

The results of our analysis show how tourist destination 
attractiveness is affected by nine drivers:

- tourist flows (constituted by two sub-drivers: GDP per capita and density),

- the real output index of a destination attractiveness;

- accessibility (related to roads, railways and airports) [3];

- natural elements, like number of protected areas, of natural parks, coasts, mountains, lakes, climate conditions (daily duration of sun light, amount of precipitations) $[52,7,53]$;

- cultural attractions (i.e. number of museums, of visitors of museums, of churches, of other monuments) [54];

- accommodations (number of hotels and of other kinds of accommodations) [55];

- recreational attractions like restaurants, bar, discos, cinemas $[1,56]$;

- tourist prices level;

- and public investments.

From the review of literature, also, safety [57] and hygiene [58] have been considered but, during the process of validation, they have been eliminated because the data are not accessible at regional or provincial level and a comparison would be impossible. The final framework of drivers and sub-drivers of tourist destination attractiveness is shown in Table 1.

Table 1. Framework of tourist destination attractiveness (TDA)

\begin{tabular}{|c|c|}
\hline Drivers & Scores assigned \\
\hline Tourist flows & 18 \\
\hline GDP pro capite & 9 \\
\hline Density & 9 \\
\hline Accessibility & 15 \\
\hline Roads km & 5 \\
\hline Railways km & 5 \\
\hline airports & 5 \\
\hline Natural elements & 15 \\
\hline n. of protected areas & 3 \\
\hline n. of natural parks & 3 \\
\hline Coasts & 3 \\
\hline Mountains & 3 \\
\hline Lakes & 3 \\
\hline Climate conditions & 12 \\
\hline Daily duration. of sunshines & 6 \\
\hline N. of precipitations & 6 \\
\hline Cultural attractions & 10 \\
\hline n. of museums & 2.5 \\
\hline $\mathrm{n}$. of visitors of museums & 2.5 \\
\hline n. of churches & 2.5 \\
\hline n. of other monuments & 2.5 \\
\hline Accomodation & 8 \\
\hline n. of hotel & 4 \\
\hline $\mathrm{n}$. of other accomodations & 4 \\
\hline Recreational attractions & 8 \\
\hline n. of restaurants & 2 \\
\hline n. of bar & 2 \\
\hline n. of disco & 2 \\
\hline n. of cinema & 2 \\
\hline Prices level & 8 \\
\hline Public investments & 6 \\
\hline Total scores & 100 \\
\hline
\end{tabular}

Table 2. Levels of tourist destination attractiveness (TDA)

\begin{tabular}{lll}
\hline Classes & Scores & Level of TDA \\
\hline 1 & $1-20$ & Low \\
2 & $21-40$ & Quite low \\
3 & $41-60$ & Discrete \\
4 & $61-80$ & Quite high \\
5 & $81-100$ & High \\
\hline
\end{tabular}

After this first step, selected stakeholders have distributed 100 scores among different drivers on the basis of their contribution to destination attractiveness, according to their previous experiences.

The highest scores have been attribute to tourist flows (18 scores), accessibility (15 scores) and natural elements (15 scores): it is particular how these elements represent respectively an output driver (tourist flows), an input driver (natural elements) and an element of facilitation to enter in a certain tourist destination (accessibility). Drivers considered as less important are accommodations (8 scores), recreational attractions (8 scores), regional prices levels (8 scores) and investments (6 scores). Scores assigned to drivers are then shared among sub-drivers in equal parts.

The application of this framework to specific tourist destination will allow, throughout SPSS, to segment different sub-drivers in four different classes. It attributes them a different score upon the basis of their class. Successively, summing up the scores of each sub-driver, it will be possible to get the TDAI that can assume a minimum value of 0 and a maximum of 100. TDAI will be classified in five different classes as shown in Table 2.

With respect to Tourist Destination Governance, our framework is based on 6 different variables which are results of previous researches by Beritelli [28] and Nunkoo et al. [41]:

- network vs. hierarchy [28-30];

- cooperative vs. non-cooperative behavior [28, 33, 34];

- consensus/involvement vs. non-consensus/non-involvement [36-39, 14];

- openness vs. closure [40];

- political trust [41].

Table 3. Kind of tourist destination governance (TDG)

\begin{tabular}{llllll}
\hline & 1 & $\mathbf{2}$ & $\mathbf{3}$ & $\mathbf{4}$ & $\mathbf{5}$ \\
\hline Hierarchy (vs Network) & & & & \\
Strategic decisions are taken by people settled in \\
power positions \\
The proposals of people in power positions are \\
submitted in some ways to other actors (firms, \\
tourists, citizens) for the approval \\
Strategic decisions are the result of a shared \\
process among all the actors involved but \\
respecting hierarchical roles \\
Cooperative (vs not cooperative) behavior \\
The different tourist organizations cooperate for \\
common purposes \\
The different tourist firms cooperate together \\
Supplier and users of tourist services need to \\
collaborate in service definition also if there is a \\
standard to respect \\
Supplier and users need to collaborate in
\end{tabular}




\begin{tabular}{|c|c|c|c|c|c|}
\hline & 1 & 2 & 3 & 4 & 5 \\
\hline $\begin{array}{l}\text { product definition also if the supplier has } \\
\text { sufficient capacity }\end{array}$ & & & & & \\
\hline Consensus (vs not consensus) & & & & & \\
\hline $\begin{array}{l}\text { There is a formal consensus in networks of } \\
\text { actors with regard to strategic issues }\end{array}$ & & & & & \\
\hline $\begin{array}{l}\text { The choices taken by tourist managers are } \\
\text { shared by tourists }\end{array}$ & & & & & \\
\hline $\begin{array}{l}\text { Tourists are involved in strategic decisions of } \\
\text { tourist governors }\end{array}$ & & & & & \\
\hline Openness (vs closure) & & & & & \\
\hline $\begin{array}{l}\text { Tourist destination cooperate in specific } \\
\text { projects with other destinations }\end{array}$ & & & & & \\
\hline $\begin{array}{l}\text { Tourist destination share tourist services with } \\
\text { other destinations }\end{array}$ & & & & & \\
\hline $\begin{array}{l}\text { Tourist destination has created tourist paths } \\
\text { including also other destinations }\end{array}$ & & & & & \\
\hline Political Trust & & & & & \\
\hline $\begin{array}{l}\text { Tourist Government is able to deliver effective } \\
\text { polices in the eyes of people }\end{array}$ & & & & & \\
\hline $\begin{array}{l}\text { Tourist Governors deserve the trust of } \\
\text { individuals because able to offer good } \\
\text { performances in the destination }\end{array}$ & & & & & \\
\hline $\begin{array}{l}\text { Tourist Governors deserve the trust of } \\
\text { individuals because a good governance is their } \\
\text { duty }\end{array}$ & & & & & \\
\hline
\end{tabular}

In order to allow the evaluation of each dimension and obtain a final level of TDG, every dimensions has been described by a number of 3-4 sentences (Table 3) that should be evaluated for each specific destination by selected stakeholders throughout a 5-points Likert Scale.

This will allow us to calculate TDGIj and, finally, TDGI, whose value will be included in the range 1 (lowest value) - 5 (highest value). Thus, also in this case, TDG will be structured in 5 different levels as shown in Table 4.

Table 4. Levels of tourist destination attractiveness (TDA)

\begin{tabular}{ll}
\hline Classes & Level of TDA \\
\hline $0-1$ & Low \\
$1,1-2$ & Quite low \\
$2,1-3$ & Discrete \\
$3,1-4$ & Quite high \\
$4,1-5$ & High \\
\hline
\end{tabular}

Crossing the results obtained throughout the computation of TDAI and TDGI, makes it possible to structure a destination in the matrix TDA-TDG proposed in Table 5.

\section{Resulting Outputs for Tourist Destinations: The Positioning Matrix}

The matrix proposed (Table 5), adopting a comparable framework to territories positioning proposed by Lemaire [21, 45], associates two different axes (Destination Governance and Attractiveness), the first assuming a value between low and excellent while the second between low and high.

In such a way, the tourist destination could be classified in seven different "boxes"on the basis of its position:

- Indisputable [21, 45]diamond tips, if it shows both a good or excellent governance and a quite high or high attractiveness: these destinations are those in the best position and they will be the benchmarks for other destinations;

- Inoperative destinations, if they are attractive but show a low or quite low governance level: probably they can count on a rich baggage of resources or natural attraction that make them attractive despite their unsatisfying governance;

- Insistent destinations, if they are in the opposite position of the previous one: in this case, they can count on a good or excellent governance but they fail to become attractive for the lack of resources or natural attractions or because of an inefficient marketing;

- Immature destinations, if they perform bad with reference both to attractiveness and governance: they have only margins for improvement;

- Promises, if they show discrete value in one dimension and high or quite high value in the other one: they are in a transition position towards the best one that is diamond tips;

- "on sunset boulevard" destinations, if they show discrete value in one dimension and low or quite low value in the other one: they are shifting towards the worst position, i.e. Immature destinations;

- "in the middle" destinations are all those destinations showing discrete value for both the dimensions: for these destination the game is open and it will depend on their ability to develop their governance and develop their attractiveness.

Table 5. Matrix TDA-TDG

\begin{tabular}{lllll}
\hline & & D.G. & & Low \\
\cline { 3 - 5 } & Excellent & Good & Discrete & Quite low \\
\hline \multirow{2}{*}{ D.A. } & Quite high & Indisputable & Promises & Inoperative destinations \\
& Discrete & Promises & "in the middle” destination & On sunset boulevard destinations \\
& Quite low & Insistent destinations & On sunset boulevard destinations & Immature destinations \\
\hline
\end{tabular}

This matrix can constitute a very important framework for Authorities, tourist organizations and managers in order to analyze the position of a particular tourist destination and to draw suitable development strategies. 


\section{Conclusive Remarks towards Implications for Tourist Destination Stakeholders}

By integrating ideas from tourism management, governance and attractiveness, this theoretical study proposes a useful framework for tourist managers to outline development plans, starting from the measure of two very important dimensions: tourist destination attractiveness and governance. In fact, despite the numerous attempts to define tourist destination attractiveness and governance, there are no identified contributions concerning the analysis of these important elements in a systemic way. The measure of TDA is very important for the determination of the attractiveness of individual tourism attraction groups and of the main pull factors towards particular destinations [1], while the second measure allows to understand which norms, rules and routines prevail in tourist destination communities, in order to better manage and govern the processes of planning, implementing and controlling for the destination [28]. Results show how each of these two dimensions could be affected by several drivers, each of which contributes, in a different way, in the determination of TDAI [2] and TDAG. The framework proposed in this paper could be very useful as it allows to individuate, following an analysis to decision approach [45] the correct position of a tourist destination and the specific drivers on which is necessary to insist in order to improve its ranking.

Starting from these results, it's possible to draw paths of action, both for TDA and for TDG. In fact the matrix TDA-TDG is also a prescriptive model, capable of driving tourist destination managers towards the identification of the most suitable development strategies for each destination. In particular, indisputable, being in the best position, should focus their efforts in the valorization of their current governance and attractiveness in order not to lose this very good position; inoperative should develop their governance in order to conserve or develop, in the future, their current attractiveness; for insistent destinations, a strategy able to improve the current attractions or to propose innovative solution or a most efficient marketing strategy could be developed in order to move towards promises and then towards indisputable. Immature destinations have very few possibilities to become attractive destination because they have to rely in some external support (eg. Multigovernmental Institutions) on the development of several drivers of attractiveness and on the dimensions of TDG: of course this process would be very long and complex.

Promises are the closest destinations to indisputable: for them, small adjustments and effort in TDA or TDG could be enough to move these destinations to the best position in the matrix. "On sunset boulevard" destinations need meaningful improvements, either on some drivers of attractiveness or on some aspects of their governance; because, if this doesn't happen, they will start to become immature destinations. Finally, the least clear position is that of "in the middle" destinations: for them the game is open and their success or failure will depend from how they will be able to manage the different drivers of the two dimensions, pushing them toward the best or the worst positions.

Although this work offers important issues and enrich existent literature, there are some limitations which should be taken into account. This paper is only a theoretical study, able to describe a framework for tourist destination but it lacks a practical application. It is possible to apply the TDA-TDG matrix to specific destinations in order to propose important comparison at national and international level as to propose and precise appropriate strategies .

\section{References}

[1] D. Krešić, and D. Prebežac, "Index of destination attractiveness as a tool for destination attractiveness assessment", Tourism, Vol. 59, No. 4, 2011, pp. 497-517.

[2] M. Viassone, "On the choice of a mountain tourist destination. The evaluation of drivers by young people", Enlightening Tourism. A Pathmaking Journal, Vol. 2, No. 2, 2012, pp. 26-46.

[3] M.F. Cracolici, P. Nijkamp, "The attractiveness and competitiveness of tourist destinations: A study of Southern Italian regions", Tourism Management, Vol. 30, No. 3, 2008, pp. 336-344.

[4] H. Zhang, "Studies on tourist destination governance from the perspective of institutional economics: Retrospect and prospect", in IPEDR, International Proceedings of Economics Development \& Research, Vol. 12, Singapore: IACSIT Press, 2011, pp. 217-221.

[5] S. Vengesayi, "A conceptual model of tourism destination competitiveness and attractiveness", in Anzmac 2003 Conference Proceedings. Adelaide, 2003, pp. 637-647.

[6] S. Formica, and M. Uysal, "Destination attractiveness based on supply and demand evaluations: An analytical framework", Journal of Travel Research, Vol. 44, No. 4, 2006, pp. 418-430

[7] Y. Hu, B.J.R. Ritchie, "Measuring destination attractiveness: A contextual approach〉, Journal of Travel Research, Vol. 32, $\mathrm{N}^{\circ}$ 2, 1993, pp. 25-34.

[8] T. Cuccia, and I. Izzo, "Heritage and tourism: Theoretical and empirical issues", Tourismos: An International Multidisciplinary Journal of Tourism, Vol. 6, No. 3, 2011, pp. 37-56.

[9] B.J.R. Ritchie, and G.I. Crouch, The Competitive Destination: A Sustainable Tourism Perspective, Wallingford: CABI Publishing, 2005.

[10] UNWTO. Sustainable Tourism Development: Guide for Local Planners, Madrid: UNWTO, 1993.

[11] X. Jin, K. Weber, and T. Bauer, "Dimensions and perceptional differences of exhibition destination attractiveness: The case of China”, Journal of Hospitality \& Tourism Research, Vol. 37, No. 4, 2012, pp. 447-469.

[12] B. Amelung, S. Nicholls, "Implications of climate change for tourism in Australia", Tourism Management, Vol. 41, 2014, pp. 228-244. 
[13] P.F.J. Eagles, "Governance and recreation and tourism partnership in parks and protected areas", Journal of Sustainable Tourism, Vol. 17, No. 2, 2009, pp. 231-248.

[14] B. Bramwell, and B. Lane, "Critical research on the governance of tourism and sustainability", Journal of Sustainable Tourism, Vol. 19, No. 4/5, 2011, pp. 411421.

[15] C.M. Hall, "A typology of governance and its implications for tourism policy analysis", Journal of Sustainable Tourism, Vol. 19, No. 4/5, 2011, pp. 437-457.

[16] H. Pechlaner, F. Raich, P. Beritelli, "Introduction to the special issue: Destination governance", Tourism Review, Vol. 65, No. 4, 2010, pp. 4-85.

[17] M. Bevir, Key concepts in governance. London: Sage, 2009.

[18] E.R. Freeman, Strategic Management: A Stakeholder Approach to Strategic Management. Boston: Pitman, 1984.

[19] R.H. Coase, "The problem of social cost", The Journal of Law and Economics, Vol. 3, No. 1, 1960, pp. 1-44.

[20] M. Jensen, and W. Meckling, "Theory of the firm: Managerial behavior, agency costs, and capital structure", Journal of Financial Economics, Vol. 3, No. 4, 1976, pp. 305-360.

[21] J.P. Lemaire, "Local authorities and foreign companies: the paradoxical issue of FDI towards fast growing economies" in The Paradoxes of Globalization, E. Milliot, and E.N. Tournois, Eds. Houndmills, Basingstoke, Hampshire: Palgrave Macmillan, 2010

[22] O.E. Williamson, "Transaction-cost economics: the governance of contractual relations", Journal of Law and Economics, Vol. 22, No. 2, 1979, pp. 233-261.

[23] J. Pfeffer, G.R. Salancik, The External Control Of Organizations: A Resource Dependence Perspective. New York: Harper and Row, 1978.

[24] P. Beritelli, T. Bieger, and C. Laesser, "Destination governance: Using corporate governance theories as a foundation for effective destination management", Journal of Travel Research, Vol. 46, No. 1, 2007, pp. 96-107.

[25] W.C. Buteau-Duitschaever, B. McCutcheon, P.F.J. Eagles, T.D. Glover, M.E. Havitz, "Park visitors' perceptions of governance: A comparison between Ontario and British Columbia provincial parks management models", Tourism Review, Vol. 65, No. 4, 2010, pp. 31-50.

[26] F. Raich, Governance räumlicher wettbewerbseinheiten ein ansatz für die tourismus-destination, Wiesbaden, Dt. Univ.-Verl., 2006.

[27] S. Nordin, and B. Svensson, "Innovative destination governance: the Swedish ski resort of Are", Entrepreneurship and Innovation, Vol. 8, No. 1, 2007, pp. 53-66.

[28] P. Beritelli, "Tourist destination governance through local elites - Looking beyond the stakeholder level", Working paper, St. Gallen: University of St. Gallen Institute for Systemic Management and Public Governance, 2011, pp. 1-43.

[29] H.A. Simon, The Sciences of the Artificial (2nd Ed.), Cambridge, Ma.: MIT Press, 1981.

[30] D. Krackhardt, "Graph theoretical dimensions of informal organizations. Computational organization theory", in Computational Organizational Theory, K. Carley, and M.
Prietula, Eds. Hillsdale, NJ: Lawrence Erlbaum Associaties, Inc., 1994, pp. 89-111.

[31] P. Beritelli, "Measuring hierarchy in elite networks of tourist destinations - A look beyond the measures of power and centrality", in Conference Proceedings 42th TTRA Annual International Conference 2011. London, Ontario, 2011, pp. 1-11.

[32] C.P. Tang, and S.Y. Tang, "Democratization and capacity building for environmental governance: managing land subsidence in Taiwan", Environment and Planning A, Vol. 38, No. 6, 2006, pp. 1131-1147.

[33] T. Dedeurwaerdere, "The contribution of network governance to sustainable development: a case study on sustainability impact assessment”, 2004. Available from: http://www.iddri.org/Evenements/Seminaires-reguliers/s13_de deurwaerdere.pdf (Accessed: $14^{\text {th }}$ November 2013).

[34] E. Laws, H. Richins, G. Agrusa, and N. Scott, Tourist Destination Governance. Practice, Theory and Issue, Nosworthy Way, Wallighford, Oxfordshire: Cab International, 2011.

[35] T.B. Jamal, and D. Getz, "Collaboration theory and community tourism planning", Annals of Tourism Research, Vol. 22, No. 1, 1994, pp. 186-204.

[36] Y. Wang, and D.R. Fesenmaier, "Collaborative destination marketing: a case study of Elkhart County, Indiana", Tourism Management, Vol. 28, No. 3, 2007, pp. 863-875.

[37] C. Pforr, "Tourism policy in the making an Australian network study", Annals of Tourism Research, Vol. 33, No. 1, 2006, pp. 87-108.

[38] http://www.amazon.com/Wikinomics-Mass-Collaboration-Ch anges-Everything/dp/B004J8HXOA (Accessed: 15 November 2013).

[39] R. March, and I. Wilkinson, "Conceptual tools for evaluating tourism partnerships", Tourism Management, Vol. 30, No. 3, 2009 , pp. $455-462$.

[40] P. Beritelli, A. Strobl, and M. Peters, "Community closure and social capital against interlocking directorates: A trade-off for development in tourist destinations", in Conference Proceedings 2011 EURAM 11th Annual Conference. Tallinn, 2011.

[41] R. Nunkoo, R. Haywantee, and D. Gursoy, "Public trust in tourist institutions", Annals of Tourism Research, Vol. 39, No. 3, 2012, pp. 1538-1564

[42] N.C. Dalkey, The Delphi Method: An Experimental Study of Group Opinion, Santa Monica (CA): Rand Corporation, 1969.

[43] C. Okoli, and S.D. Pawlowski, The Delphi method as a research tool: an example, design considerations and applications, Information \& Management, Vol. 42, No. 1, 2004, pp. 15-29

[44] M. Viassone, and C. Casalegno, "Does a correlation between provincial and district competitiveness exist? the study of italian areas", World Journal of Social Sciences, Vol. 1, No. 5, 2011, pp. 36-53.

[45] J.-P. Lemaire, Strategies d'Internationalisation. Nouveaux Enjeux d'ouverture des Organization, des Activités Et Des Territoires. Paris : Dunod, 2013.

[46] G. Marzano, and N. Scott, "Power in destination branding", Annals of Tourism Research, Vol. 36, No. 2, 2009, pp. 247-267.

[47] A. Presenza, M. Cipollina, "Analysing tourism stakeholders 
networks", Tourism Review, Vol. 65, No. 4, 2010, pp. 17-30.

[48] G. Saxena, "Beyond mistrust and competition-the role of social and personal bonding processes in sustaining livelihoods of rural tourism businesses: A case of the Peak District National Park", International Journal of Tourism Research, Vol. 8, No. 4 2006, pp. 263-277.

[49] J.J. Cronin, and S.A. Taylor, "Measuring service quality: Are-examination and extension", Journal of Marketing, Vol. 56, No.3, 1992, pp. 55-68.

[50] R. Likert, "A tecnique for the measurement of attitudes", Archives of Psycology, No. 140, 1932.

[51] G. Tardivo, A. Scilla, and M. Viassone, "'Codice QR': una risposta innovativa per la comunicazione e la soddisfazione del cliente», in Sinergie, Referred Electronic Conference Proceeding of the XXV Convegno annuale di Sinergie «L'innovazione per la competitività delle imprese», Verona: Sinergie, 2013, pp. 429-444.

[52] D. Jani, C.I. Jang, Y-H. Hwang, "Differential effects of tourism resources on the attractiveness of destination bundles", International Journal of Tourism Sciences, Vol. 9, No. 1, 2009, pp. 23-36.
[53] S. Shoemaker, "Segmenting the U.S. travel market according to benefits realized", Journal of Travel Research, Vol. 32, No. 3, 1994, pp. 8-21.

[54] OECD, The Impact Of Culture On Tourism. Centre for Entrepreneurship, SMEs and Local Development, 2009.

[55] V. Della Corte, La Gestione dei Sistemi Locali di Offerta Turistica. Padova: Cedam, p.

[56] M. Symons, "Gastronomic authenticity and sense of place", in Proceedings of the 9th Australian Tourism Hospitality Research Conference. Camberra: Council for Australian University Tourism and Hospitality Education, BTR, 1999, pp. 333-340.

[57] Y.K. Mak, Safety First, 2007, Available at http://ttgmice.com/index.php?option=com_content\&task=vie w\&id $=2677 \&$ Itemid $=89$, (Accessed $13^{\text {th }}$ October $)$.

[58] C.H. Van Heerden, Y. Botha, E. Durieux, "The relationship between atmospherics, services cape and destination attractiveness of a holiday destination", Innovative Marketing, Vol. 5, No. 1, 2009, pp. 55-65. 